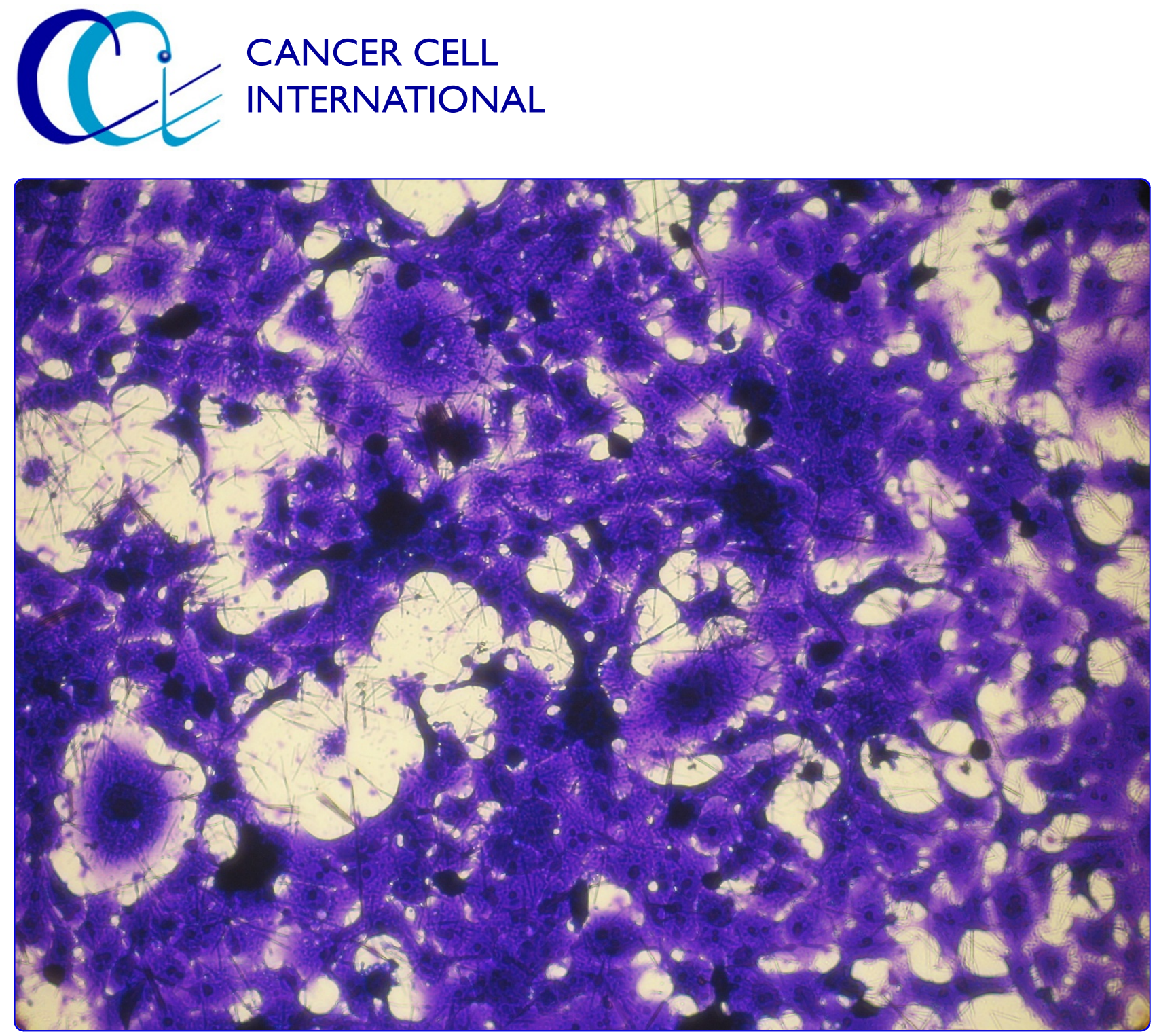

Folic acid supplementation increases survival and modulates high risk HPV-induced phenotypes in oral squamous cell carcinoma cells and correlates with p53 mRNA transcriptional down-regulation Moody et al. 


\title{
Folic acid supplementation increases survival and modulates high risk HPV-induced phenotypes in oral squamous cell carcinoma cells and correlates with p53 mRNA transcriptional down-regulation
}

Michael Moody ${ }^{1}$, Oanh Le ${ }^{1}$, Megan Rickert ${ }^{1}$, Jeremy Manuele ${ }^{1}$, Sarah Chang ${ }^{1,2}$, Gary Robinson², Jeffrey Hajibandeh ${ }^{2,3}$, John Silvaroli ${ }^{2,4}$, Mark A Keiserman ${ }^{5}$, Christine J Bergman ${ }^{6}$ and Karl Kingsley ${ }^{1 *}$

\begin{abstract}
Background: Although the primary risk factors for developing oral cancers are well understood, less is known about the relationship among the secondary factors that may modulate the progression of oral cancers, such as high-risk human papillomavirus (HPV) infection and folic acid (FA) supplementation. This study examined high-risk HPV and FA supplementation effects, both singly and in combination, to modulate the proliferative phenotypes of the oral cancer cell lines CAL27, SCC25 and SCC15.

Results: Using a comprehensive series of integrated in vitro assays, distinct effects of HPV infection and FA supplementation were observed. Both high-risk HPV strains 16 and 18 induced robust growth-stimulating effects in CAL27 and normal HGF-1 cells, although strain-specific responses were observed in SCC25 and SCC15 cells. Differential effects were also observed with FA administration, which significantly altered the growth rate of the oral cancer cell lines CAL27, SCC15, and SCC25, but not HGF-1 cells. Unlike HPV, FA administration induced broad, general increases in cell viability among all cell lines that were associated with p53 mRNA transcriptional downregulation. None of these cell lines were found to harbor the common C677T mutation in methylenetetrahydrofolate reductase (MTHFR), which can reduce FA availability and may increase oral cancer risk.

Conclusion: Increased FA utilization and DNA hypermethylation are common features of oral cancers, and in these cell lines, specifically. The results of this study provide further evidence that FA antimetabolites, such as Fluorouracil ( $55 \mathrm{U}$ or $5-\mathrm{FU}$ ) and Raltitrexed, may be alternative therapies for tumors resistant to other therapies. Moreover, since the incidence of oral HPV infection has been increasing, and can influence oral cancer growth, the relationship between FA bioavailability and concomitant HPV infection must be elucidated. This study is among the first preclinical studies to evaluate FA- and HPV-induced effects in oral cancers, both separately and in combination, which provides additional rationale for clinical screening of HPV infection prior to treatment.
\end{abstract}

Keywords: Folate, Human papillomavirus, Oral cancer

\section{Background}

Oral cancers take many years or decades to develop and may involve many separate, but inter-related processes $[1,2]$. Epidemiologic studies have provided evidence that tobacco and alcohol use are the major oral cancer risk

\footnotetext{
* Correspondence: karl.kingsley@unlv.edu

'Department of Biomedical Sciences, School of Dental Medicine, University of Nevada, Las Vegas, USA

Full list of author information is available at the end of the article
}

factors, because of their direct and indirect carcinogenic effects on oral tissues [3,4]. During this lengthy process of carcinogenesis, many other factors are known to interact with, and modulate, oral tumor growth, including diet and infectious agents [5,6].

For example, a growing body of evidence has demonstrated that human papillomavirus (HPV) is a separate, independent oral cancer risk factor $[7,8]$. The high-risk HPV types involved in cervical carcinogenesis, HPV16

\section{C) Biomed Central}


and HPV18, are present in a significant subset of oral cancers, and may contribute to oral carcinogenesis by similar mechanisms $[7,9,10]$. More specifically, the HPV "early" oncoproteins, E6 and E7, which promote viral replication, also bind $p 53$ and disrupt tumor suppressor functions of retinoblastoma $(R b)$ and $B c l-2$ [11]. Thus, infected cells bypass traditional G1/S cell cycle checkpoints disrupting the normal cell cycle. This disruption ultimately propels cell proliferation and drives carcinogenesis. More recent evidence also demonstrates HPV infection may function to modulate the growth of already existing oral tumors [12,13].

Despite understanding the primary mechanisms of HPV-mediated carcinogenesis [14], less is known about the secondary factors that modulate this transformation. A critical factor of HPV progression is methylation of the HPV genome $[15,16]$. Site-specific CpG methylation, mediated in part by adequate methyl donor availability (folate sufficiency), may be sufficient to slow or suppress HPV-driven carcinogenesis [17,18]. Partial demethylation or hypomethylation, which may result from inadequate methyl donor availability (folate insufficiency), is now known to be required for HPV-mediated cellular transformation [19].

Dietary folate intake facilitates specific metabolic processes, including the formation of S-adenosylmethionine, the primary methyl donor for DNA methylation reactions $[20,21]$. Human folate deficiencies are associated with many health disorders, including neural tube defects, vascular disease, microcytic anemia, and many types of cancer - including oral cancers [22-25]. Insufficient dietary intake of folate may result in dysregulation of DNA methylation, interfering with DNA synthesis and repair, which may initiate or trigger these adverse health conditions [26,27]. Some evidence now demonstrates that tobacco and alcohol use modulate folate metabolism by interfering with folate absorption and increasing renal excretion of folate, thereby lowering bioavailable folate $[5,6,28]$. In addition, previous studies also demonstrate that a common polymorphism in the methylenetetrahydrofolate reductase (MTHFR) gene, coding for the enzyme that produces the circulating form of folate, decreases function and capacity of this enzyme while increasing oral cancer risk $[29,30]$.

To reduce the incidence of neural tube defect pregnancies associated with folate deficiency, the US Food and Drug Administration (FDA) adopted requirements for folate fortification of many food products starting in 1996 [31]. These measures were associated with an increase in mean dietary folate intake within the population, and a reduced incidence of neural tube defects and other folate deficiency-associated health conditions [32]. However, although folate sufficiency protects normal, non-neoplastic cells from turning cancerous through maintainance of normal DNA synthesis, repair and methylation, an opposite effect of supplementation on pre-existing early-stage colorectal cancers has been noted [33,34]. Most recently, some evidence now suggests that folate supplementation may also drive the growth and proliferation of oral cancers $[35,36]$.

A thorough investigation of the inter-connected and inter-related mechanisms of the secondary factors that may modulate the growth and progression of oral cancers, such as high-risk HPV infection and folate supplementation is needed to elucidate these relationships. The purpose of this study is to elucidate the potential for high-risk HPV and folate supplementation, both singly and in combination, to modulate the proliferative phenotypes of well-characterized oral cancer cell lines.

\section{Materials and methods \\ Cell culture}

The human OSCC cell lines used in this study, CAL27 (CRL-2095), SCC15 (CRL-1623), SCC25 (CRL-1628), and HGF-1 (CRL-2014) were obtained from American Type Culture Collection (ATCC: Manassas, VA). CAL27 cells were maintained in Dulbecco's Modified Eagle's Medium (DMEM) with $4 \mathrm{mM} \mathrm{L-glutamine,} \mathrm{adjusted} \mathrm{to}$ contain $3.7 \mathrm{~g} / \mathrm{L}$ sodium bicarbonate and $4.5 \mathrm{~g} / \mathrm{L}$ glucose from Hyclone (Logan, UT). SCC15 and SCC25 cells were maintained in a 1:1 mixture of DMEM and Ham's F12 medium with $2.5 \mathrm{mM}$ L-glutamine, modified to contain $15 \mathrm{mM}$ HEPES, $0.5 \mathrm{mM}$ sodium pyruvate, and $1.2 \mathrm{~g} / \mathrm{L}$ sodium bicarbonate (ATCC), supplemented with $400 \mathrm{ng} / \mathrm{ml}$ hydrocortisone from Sigma-Aldrich (St. Louis, MO). The control oral cell line HGF-1 (CRL2014) was maintained in DMEM with $4 \mathrm{mM}$ L-glutamine, adjusted to contain $3.7 \mathrm{~g} / \mathrm{L}$ sodium bicarbonate and $4.5 \mathrm{~g} / \mathrm{L}$ glucose, from Hyclone (Logan, UT). Media for all cell lines was supplemented with $10 \%$ fetal bovine serum (FBS), and with $1 \%$ Penicillin $(10,000$ units $/ \mathrm{mL})$ Streptomycin $(10,000 \mu \mathrm{g} / \mathrm{mL})$ solution (HyClone). Cell cultures were maintained in $75 \mathrm{~cm}^{2}$ Becton, Dickinson (BD) Falcon tissue-culture treated flasks (Bedford, MA) at $37^{\circ} \mathrm{C}$ and $5 \% \mathrm{CO}_{2}$ in humidified chambers.

\section{Materials}

Folic acid (FA) with molecular weight $(\mathrm{MW})=441.40$ was obtained from Fisher Bioreagents (Fair Lawn, New Jersey. Lot\#075677). Proliferation and viability assays were performed in the appropriate complete media, with and without the addition of FA $(100 \mu \mathrm{g} / \mathrm{mL}, 400 \mu \mathrm{g} /$ $\mathrm{mL})$. These concentrations represent $0.23 \mathrm{mM}$ and 0.91 mM FA, supraphysiologic concentrations which allow for short-term in vitro effects to be observed.

$100 \mu \mathrm{g} / \mathrm{mL}=100 \mathrm{mg} / \mathrm{L}=0.1 \mathrm{~g} \mathrm{FA} / 441.4 \mathrm{MW}=$ 0.0002265 or $0.23 \mathrm{mM} 400 \mu \mathrm{g} / \mathrm{mL}=400 \mathrm{mg} / \mathrm{L}=0.4 \mathrm{~g}$ $\mathrm{FA} / 441.4 \mathrm{MW}=0.0009062$ or $0.91 \mathrm{mM}$ 
The US population mean folate serum concentration range is $2.7 \mathrm{nM} / \mathrm{L}$ and $11.4 \mathrm{nM} / \mathrm{L}$, which corresponds with low-range and average US population folic acid equivalents intake measures, as of $2005(79-376 \mu \mathrm{g} / \mathrm{mL})$ [37]. The media used for these experiments, DMEM or Ham's F-12, with $10 \%$ FBS each contain $2.3 \mu \mathrm{M}$ FA or the equivalent of $1.015 \mu \mathrm{g} / \mathrm{mL}$, which is approximately $0.25-1 \%$ of the experimental concentrations used [38].

\section{Transfection}

CAL27, SCC15, SCC25, and HGF-1 cells were seeded in $25 \mathrm{~cm}^{2}$ BD Falcon tissue-culture treated flasks in appropriate media as described above and allowed to achieve $70 \%$ confluence. Cells were then transiently transfected by adding $1 \mu \mathrm{g} / \mathrm{mL}$ of the full-length HPV type 16, cloned into the pBluescript SK-vector (ATCC \#45113) or the HPV type 18, cloned into the pBR322 vector (ATCC \#45152). The transfections were performed using the Stratagene Mammalian Transfection Kit (La Jolla, CA) according to the manufacturer's recommended protocol for $\mathrm{CaPO}_{4}$ transfection. Mock transfectants (mTF) of each cell line were also established by performing the same transfection protocol, but without using virus. Transfections were confirmed by RT-PCR analysis of HPV mRNA production using extracted cellular RNA.

\section{Proliferation}

Proliferation assays were performed using cell lines, transfected with HPV16, HPV18, and non-transfected controls, with and without the addition of FA $(100 \mu \mathrm{g} /$ $\mathrm{mL}, 400 \mu \mathrm{g} / \mathrm{mL}$ ). Proliferation assays were performed in the appropriate complete media in Corning Costar 96-well assay plates (Corning, NY) at a concentration of $1.2 \times 10^{4}$ cells per well, and proliferation was measured over three days. Cultured cells were fixed at three time points, after $24 \mathrm{hrs}$ (day 1 ), after $48 \mathrm{hrs}$ (day 2), and after 72 hrs (day 3) using $50 \mu \mathrm{L}$ of $10 \%$ buffered formalin, and were stained with crystal violet 1\% aqueous solution (Fisher Scientific: Fair Lawn, NJ). The relative absorbance was measured at $630 \mathrm{~nm}$ using a Bio-Tek ELx808 microplate reader (Winooski, VT). Data were analyzed and graphed using Microsoft Excel (Redmond, WA) and SPSS (Chicago, IL). Three separate, independent replications of each experiment were performed.

\section{Relative-fold increase in proliferation}

Trypsinizing and plating cells may have proliferation-stimulating effects within laboratory cell culture-based assays, which have been observed between $\mathrm{d} 0$ and $\mathrm{d} 1$ in previously published work involving this specific method of proliferation assay in these cell lines [36,39]. To reduce the overall impact of these effects, the relative change in proliferation, measured as the change or relative-fold increase (RFI) in absorbance between $\mathrm{d} 3$ and d1, can be calculated to more accurately assess the changes induced by these experimental treatments.

\section{Statistics}

Comparisons of the effects of treatments were made using two-tailed $t$ tests with $\alpha=.05$. All samples were analyzed using two-tailed $t$ tests as departure from normality can make more of a difference in a one-tailed than in a two-tailed $t$ test [40]. As long as the sample size is even moderate $(>20)$ for each group, quite severe departures from normality make little practical difference in the conclusions reached from these analyses. To confirm the effects observed from these experiments, further analysis of the data was facilitated with ANOVA using SPSS (Chicago, IL). Significance for ANOVA was $p<0.05$.

\section{Survival and viability}

Prior to plating cells for proliferation assays, aliquots of trypsinized cells were stained using Trypan Blue (Sigma: St. Louis, MO), and live cells were enumerated by counting the number of Trypan-blue negative cells using a VWR Scientific Counting Chamber (Plainfield, NJ) and a Zeiss Axiovert 40 inverted microscope (Gottingen, Germany). At each time point (d1-d3), several wells were processed using the Trypan stain, and live cells were enumerated using this procedure.

\section{DNA isolation, PCR, and RFLP}

To determine if these cell lines harbored the most common DNA polymorphism in the MTHFR gene (C677T) or any endogenous HPV virus, DNA was isolated from $1.5 \times 10^{7}$ cells from each cell line using the GenomicPrep DNA isolation kit (Amersham Biosciences: Buckinghamshire, UK), using the procedure recommended by the manufacturer. DNA concentration was measured using the optical density absorbance value measured by a spectrophotometer at $260 \mathrm{~nm}$. DNA purity was calculated using ratio measurements of absorbance at 260 and $280 \mathrm{~nm}$; A260:A280 purity range should be between 1.7 and 2.0. DNA from each cell line was used to perform polymerase chain reaction (PCR) with the Fisher exACTGene complete PCR kit (Fisher Scientific: Fair Lawn, NJ) and a Mastercycler gradient thermocycler (Eppendorf: Hamburg, Germany) using the following MTHFR [41], and HPV [13,35] primers, synthesized by SeqWright (Houston, TX):

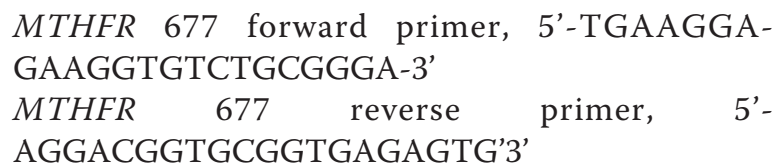
GAAGGTGTCTGCGGGA-3' 


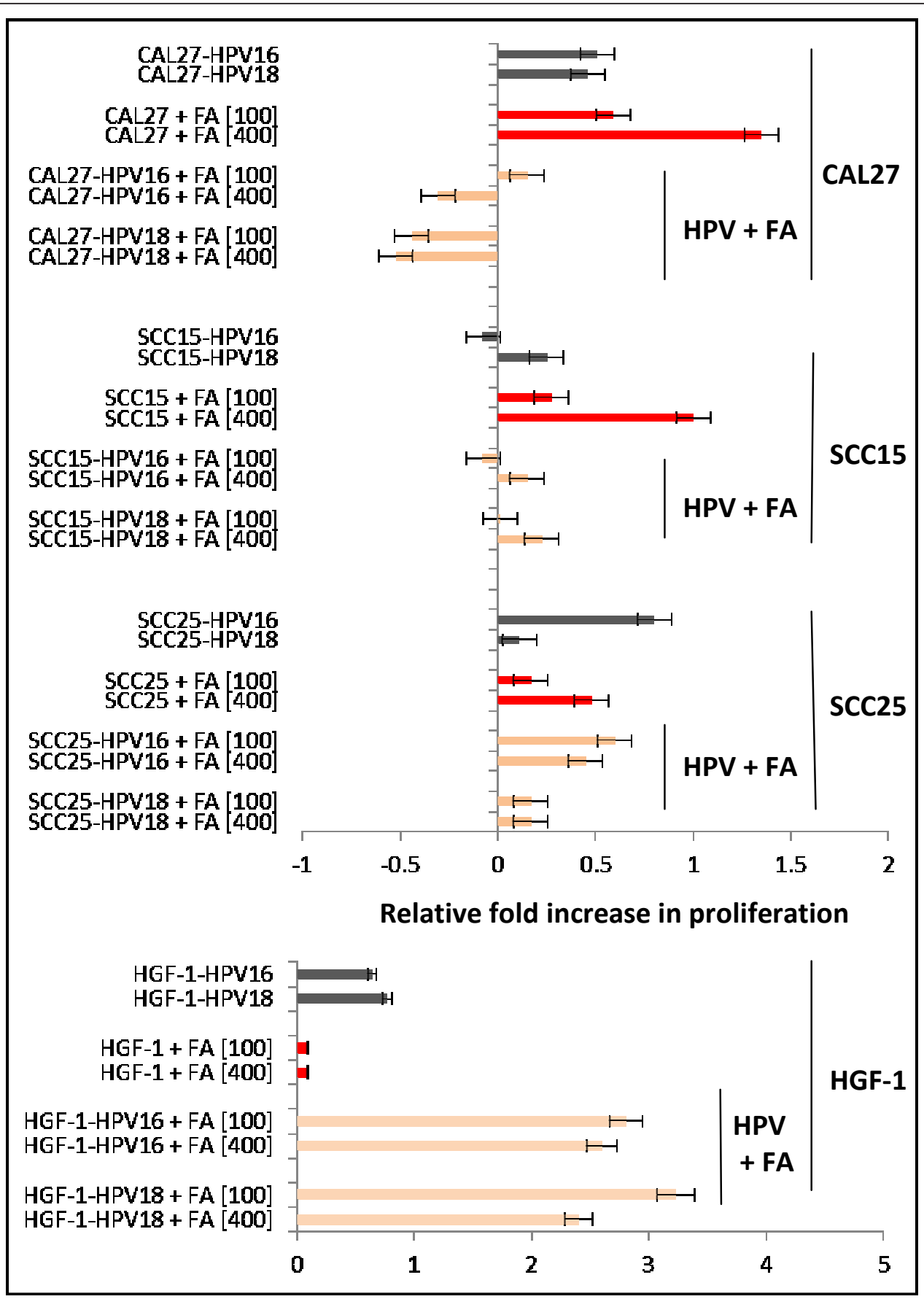

Figure 1 Measurement of relative-fold increase (RFI): FA modulation of HPV effects. Analysis of RFI in CAL27 cells revealed the growth stimulating effects of HPV16, HPV18, FA [100] and FA [400] are reduced or inhibited when HPV and FA are concomitantly administered. Similarly, SCC15 cell growth stimulated by HPV18, FA [100 $\mu \mathrm{g} / \mathrm{mL}]$ and FA $[400 \mu \mathrm{g} / \mathrm{mL}]$ is either reduced or inhibited by concomitant HPV and FA administration. SCC25 cell growth, stimulated by HPV16, FA $[100 \mu \mathrm{g} / \mathrm{mL}]$ and FA $[400 \mu \mathrm{g} / \mathrm{mL}]$ is also significantly reduced, although not completely inhibited by concomitant HPV and FA administration. HGF-1 cell growth, stimulated by HPV16 and HPV18 but not FA administration, was robustly enhanced by concomitant administration of HPV and FA. Both HPV16 and HPV18 enhanced HGF-1 proliferation at either concentration of FA [100 or $400 \mu \mathrm{g} / \mathrm{mL}]$. 
$\mathrm{mL}]$ and FA [400 $\mu \mathrm{g} / \mathrm{mL}]$. However, the combined effects of HPV16 and FA at $100 \mu \mathrm{g} / \mathrm{mL}$ did not stimulate SCC15 growth $(-0.075$-fold, $p>0.05)$, but did at $400 \mu \mathrm{g} / \mathrm{mL}(+0.15$-fold, $p<0.05)$. The combination of HPV18 and FA at $100 \mu \mathrm{g} / \mathrm{mL}$ also did not stimulate SCC15 growth (0.01-fold, $p>0.05)$, but did at $400 \mu \mathrm{g} /$ $\mathrm{mL}(+0.225$-fold, $p<0.05)$.

Finally, the combined effects of HPV16 and FA on SCC25 cells at $100 \mu \mathrm{g} / \mathrm{mL}$ strongly enhanced growth (0.6-fold, $p<0.05$ ), as did FA at $400 \mu \mathrm{g} / \mathrm{mL}$ (0.45-fold, $p$ $<0.05)$. The combined effects of HPV18 and FA on SCC 25 cells at either 100 or $400 \mu \mathrm{g} / \mathrm{mL}$ were similar, increasing growth modestly $(0.15$-fold, $p<0.05)$

Intriguingly, the effects of HPV16 and HPV18 on HGF-1 cell proliferation were strongly enhanced by FA administration. FA supplementation increased HPV16mediated HGF-1 growth by 2.8 -fold and 2.6-fold at the lower and higher concentrations evaluated $(p<0.05)$, while HPV18-mediated growth was increased by 3.2-fold and 2.4-fold at these concentrations $(p<0.05)$.

\section{Survival and viability}

To determine if the observed effects on cell growth induced by HPV transfection or FA supplementation were due, in part, to changes in cell survival, each cell line and experimental treatment were analyzed at each time point of the proliferation assays and under each of the treatment conditions (Table 1). The addition of HPV16 or HPV18 increased survival among CAL27 cells from an average of $73 \%$ in non-transfected cells to $94 \%$ and $95 \%$, respectively. Significant increases in survival were also observed under both high and low concentrations of FA.

SCC15 baseline survival (79\%) was relatively unaffected by HPV16 (80\%), but was significantly enhanced HPV18 (88\%). However, significant increases in survival were observed under both conditions of FA administration, to $94 \%(100 \mu \mathrm{g} / \mathrm{mL})$ and $91 \%(400 \mu \mathrm{g} / \mathrm{mL})$. Although HPV16 increased SCC25 survival to $86 \%$ from a baseline of $80 \%$, no such increase in survival observed with HPV18 (79\%). FA administration was associated with significant increases in SCC25 survival. Survival among HGF-1 cells (84\%) was also significantly

\section{Table 1 Cell viability}

\begin{tabular}{lcccc}
\hline & CAL27 & SCC15 & SCC25 & HGF-1 \\
\hline & $73 \%$ & $79 \%$ & $80 \%$ & $84 \%$ \\
\hline HPV16 & $\mathbf{9 4 \%}$ & $80 \%$ & $\mathbf{8 6 \%}$ & $\mathbf{9 4 \%}$ \\
\hline HPV18 & $\mathbf{9 5 \%}$ & $\mathbf{8 8 \%}$ & $79 \%$ & $\mathbf{9 3 \%}$ \\
\hline FA $[100 \mu \mathrm{g} / \mathrm{mL}]$ & $\mathbf{9 6 \%}$ & $\mathbf{9 4 \%}$ & $\mathbf{9 7 \%}$ & $\mathbf{9 1 \%}$ \\
\hline FA $[400 \mu \mathrm{g} / \mathrm{mL}]$ & $\mathbf{9 6 \%}$ & $\mathbf{9 1 \%}$ & $\mathbf{9 9 \%}$ & $\mathbf{9 3 \%}$ \\
\hline
\end{tabular}

increased by HPV16, HPV18 and FA treatments by nearly equal levels $(\sim 10 \%)$.

\section{MTHFR RFLP screening}

Because folate bioavailability may be reduced by a common DNA single nucleotide polymorphism (SNP) in the methylenetetrahydrofolate reductase (MTHFR) gene, which encodes the enzyme responsible for producing the circulating form of folate, each cell line was examined to determine if the most common MTHFR DNA polymorphism (C677T) was present. The RFLP analysis demonstrated that CAL27, SCC25, SCC15 and HGF-1 cells were not found to contain the MTHFR C677T polymorphism (Figure 2A). To rule out confounding effects of DNA concentration, absorbance measurements were taken, revealing similar DNA concentrations from each cell line, which ranged from $821-895 \mathrm{ng} / \mu \mathrm{L}$ (Figure 2B). Analysis of A260/A280 ratio confirmed the similarity of purity from the DNA isolates, which averaged between 1.76 and 1.92. PCR amplifying the housekeeping gene, GAPDH, revealed nearly identical band patterns of similar intensity (Figure 2C).

\section{p53 mRNA transcription}

Some evidence has demonstrated the differing effects of folic acid supplementation according to the $p 53$ transcription profile of the tumor. The $p 53$ mRNA transcription profile for each cell line under each experimental condition, untreated (control: $\mathrm{Ctl}$ ), FA at $400 \mu \mathrm{g} / \mathrm{mL}(+\mathrm{FA})$, HPV16 or HPV18 + FA was examined (Figure 3A). Densitometric measurements of relative end-point RT-PCR band intensity revealed administration of FA significantly reduced $p 53$ mRNA transcription in CAL27, SCC25, and SCC15 cells nearly completely. HGF-1 mRNA transcription, however, was relatively unaffected $(-5 \%)$.

The concomitant administration of HPV and FA also exhibited differential effects on $p 53$ mRNA transcription in each cell line. In CAL27 cells, p53 mRNA transcription was restored and indistinguishable from untreated CAL27 cells. In SCC25 cells, however, HPV18 + FA was associated with more than three-fourths reduction in p53 mRNA transcription (-76\%), while HPV16 + FA administration was associated with a more modest inhibition (-25\%). Interestingly, $p 53$ mRNA transcription in SCC15 cells was inhibited under all conditions evaluated, +FA, HPV16 + FA, and HPV18 + FA. The normal cell line, HGF-1, however exhibited no significant changes in p53 mRNA transcription under FA administration alone, although a nearly complete reduction under HPV16 + FA and HPV18 + FA was observed. GAPDH mRNA transcription in each cell line, however, remained relatively constant. 


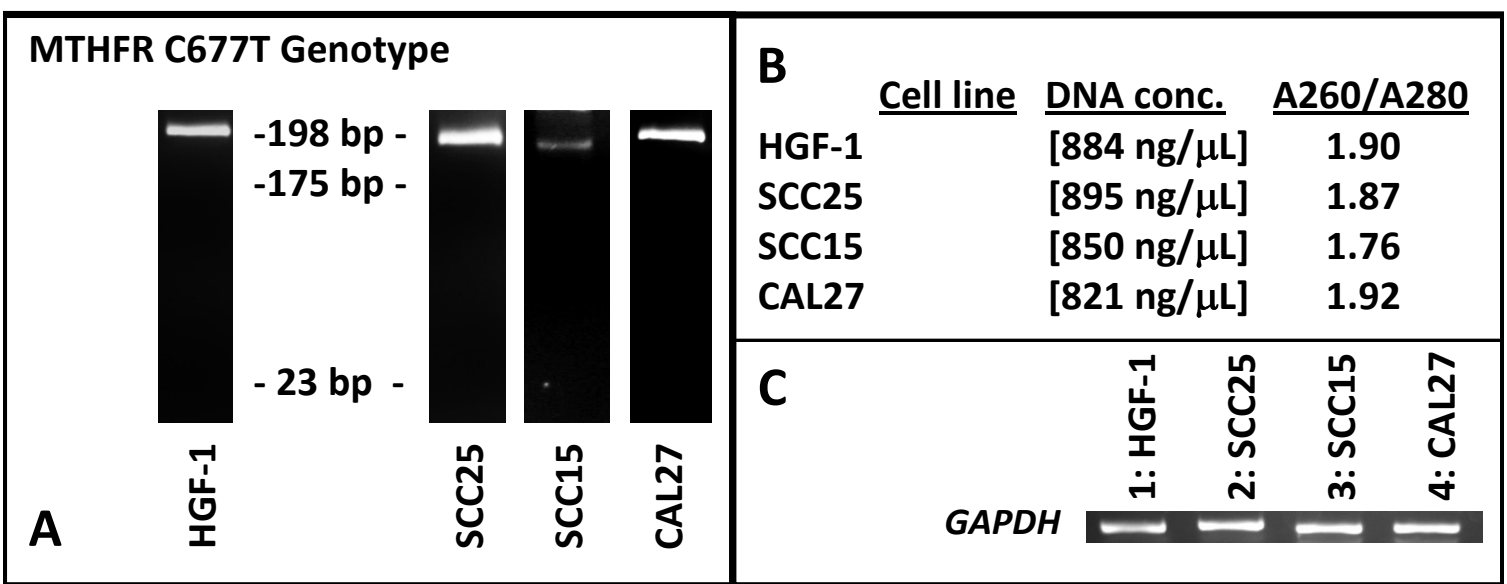

Figure 2 DNA and RFLP analysis. A) Hinf1 restriction digestion (RFLP) of PCR products (C/C: $198 \mathrm{bp}$ ) were used to screen for C677T SNP genotype of MTHFR. The C677T MTHFR polymorphism creates a Hinf1 cleavage site, yielding DNA fragment lengths of 175 bp and 23 bp in the presence of the variant T allele. The normal (HGF-1) and all three oral cancer cell lines (SCC25, SCC15, CAL27) were found to harbor wild type (C) C) genetic profiles; no heterozygotes (C/T) or homozygous mutants (T/T) were observed. B) DNA concentration and purity derived from absorbance readings at 260 and $280 \mathrm{~nm}$ revealed similar concentrations ( $821-895 \mathrm{ng} / \mu \mathrm{L})$ and purity $(1.76-1.92)$ from each cell line. C) PCR using control using GAPDH established similar band intensities from each cell line.

\section{HPV screening}

Finally, to confirm these cell lines did not already harbor endogenous HPV, which could potentially confound these observations, DNA and RNA from each cell line was used to perform PCR and RT-PCR screenings using primers specific for HPV16 and HPV18 (Figure 3B and $3 C)$. These results demonstrated that HGF-1, SCC25, SCC15 and CAL27 cells did not harbor HPV16 or HPV18 DNA (Figure 3B). DNA isolated from HPV-positive cervical cancer cell lines (CaSKi, HPV16; GH354, HPV18) was used as PCR positive controls. In addition, DNA presence post-transfection was confirmed using PCR, which demonstrated HPV-specific DNA was present each cell line, but not in the mock transfectants (mTF) (Figure 3C). In addition, HPV-specific mRNA was expressed in all cell lines following transfection, which was similar to mRNA expression levels in control cells.

\section{Discussion}

Although epidemiologists and oral health researchers concur that the majority of oral cancers originate from the use of tobacco and alcohol, recent studies have also suggested that both HPV infection and folate sufficiency accelerated oral cancer growth $[7,8,48,49]$. The goal of this study was to investigate the possibility that highrisk HPV infection and FA administration, both singly and in combination, could mediate the proliferation of well-characterized oral cancers. To test these hypotheses, a comprehensive series of integrated in vitro assays were performed that clearly demonstrated distinct effects of HPV infection and FA supplementation in each cell line examined. For example, although both high-risk HPV strains induced robust growth-stimulating effects in CAL27 and HGF-1 cells, strain-specific responses were observed in both SCC25 and SCC15 cells. These results are consistent with previous reports of HPV strain-specific effects [13], as well as evidence that oral cancers are not dependent upon the inhibition of a single signal transduction or tumor suppression pathway for growth and development [50].

It is important to note that increased survival and viability was also observed under conditions of HPV-stimulated growth. These observations suggest that modulation of either $p 53$ or $R b$-specific pathways by HPV E6 and E7 genes could be responsible for lowering the barriers to $\mathrm{G} 1 / \mathrm{S}$ cell cycle progression, thereby simultaneously increasing both the rates of proliferation as well as cell viability as previously observed [51-53]. Furthermore, that FA administration increased proliferation and simultaneously down-regulated p53 mRNA transcription in all three oral cancer cell lines, but not HGF-1 cells, strongly suggests this pathway may be, in part, critical to our understanding of these processes.

Another key finding was the observation of differential effects induced by FA administration, which significantly altered the growth rate of oral cancers, but not normal cells. This evidence suggests folate bioavailability may be a rate-limiting step among oral cancers that have impaired or reduced function in one or more cell cycle inhibition pathways, which is further supported by the observation that these dose-dependent effects can be saturated [36,54]. Unlike HPV, FA administration induced broad, general increases in cell viability among 


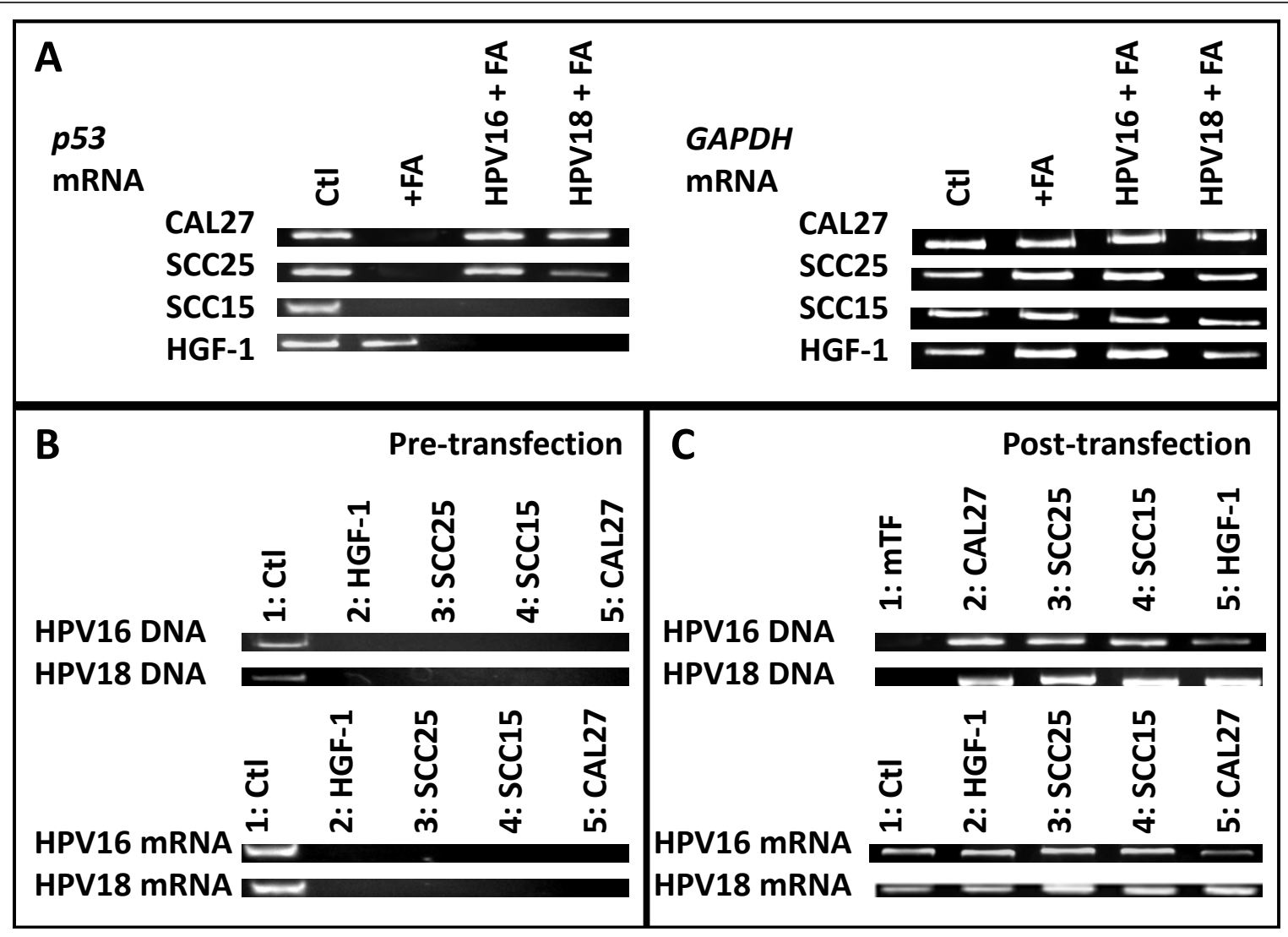

Figure 3 DNA and mRNA analysis. A) RT-PCR performed on total RNA extracted from cells at d1 (24 hr) following FA administration [400 $\mu \mathrm{g} /$ $\mathrm{mL}$ ] revealed little change in p53 mRNA transcription in HGF-1 cells, but decreased transcription in CAL27, SCC15, and SCC25 cells. HPV16 and HPV18 had little effect on FA-induced changes in p53 transcription in CAL27 and SCC25 cells, although decreases were observed in both SCC15 and HGF-1 cells. B) PCR screening from DNA confirmed HPV16 and HPV18 DNA was present in the control cell lines, CaSKi (HPV16) and GH354 (HPV18) cervical adenocarcinomas, but not HGF-1, SCC25, SCC15 or CAL27. RT-PCR screening also confirmed the presence of HPV-specific mRNA in the control, but not experimental, cell lines. C) DNA screening post-transfection confirmed the presence of HPV-specific DNA in CAL27, SCC25, SCC15 and HGF-1, but not mock transfectants (mTF); RNA screening confirmed production of HPV-specific mRNA at levels similar to control cell lines.

all cell lines, which may support the observations that folate bioavailability may also play critical roles in biosynthetic and epigenetic pathways that are not directly related to cellular growth or proliferation $[22,29,30]$. Although FA administration increased cellular viability in the normal cell line, this increase was comparatively smaller than the effects in the oral cancer cell lines, which might suggest these larger changes in survival and viability might function to exacerbate the observed proliferation-stimulating effects among oral cancers over time.

Previous studies have demonstrated the proliferation stimulating effects of HPV and FA administration on oral cancers may suggest that concomitant removal or reduction of $p 53$ and $R b$ tumor suppression pathways and increased folate bioavailability could greatly amplify cellular growth $[7,8,22,24,27]$. In fact, this was observed in the responses of the normal cell line, HGF-1.
However, the combined effects of HPV and FA administration were strikingly different, with a reduction or complete inhibition of growth observed in all three oral cancer cell lines. Further analysis revealed several studies that now confirm CpG site-specific methylation of HPV DNA, mediated in part by folate availability, is sufficient to suppress neoplastic progression $[17,18,55,56]$. Although preferential DNA methylation in $p 53$ exons 248 and 273 by DNA methyltransferases may occur during oral carcinogenesis [57,58], CpG methylation of the HPV genome is among the most important factors that limit viral production and HPV-mediated phenotypes $[15,16,59]$. Based upon this understanding, a more thorough and complete investigation is warranted to explore the role of folate in mediating the availability of methyl groups for CpG-specific DNA methylation, influencing p53 and HPV mRNA transcription, as well as biosynthetic pathways in oral cancers. 
Finally, a limitation of this and other preclinical studies involves the use of oral cancer cell lines, as there may be underlying dissimilar genetic mutations that might potentially influence the experimental outcomes. For example, the SCC25 cell line has been found to contain a deletion in the cdk1 promoter that contains a key transcriptional repressor region [60]. The CAL27 cell line contains a nonsense mutation in the SMAD4 gene, while SCC15 cells were found to harbor a missense mutation in SMAD2 - both signal TGF- $\beta$ transduction proteins [61]. In addition, both CAL27 and SCC15 cells contains a single nucleotide polymorphism in the S100A2 gene, a calcium-binding tumor suppressor protein, although this did not appear to alter their propensity for growth, migration or invasion [62]. However, a growing body of evidence demonstrates that dysregulation and reduced expression of key tumor suppressors, such as p16, in these cell lines may, in fact, be the result of hypermethylation - providing further justification to elucidate the interconnected roles of FA bioavailability and utilization may play in the growth and progression of oral cancers [63-65].

\section{Conclusions}

Although individual studies have suggested that either high-risk HPV infection or FA administration may influence the growth and progression of oral cancers, evidence is now emerging that indicates folate bioavailability and oral HPV infection are very closely inter-connected. The policy of folate food fortification, routine multivitamin use and FA supplementation, combined with an ever-increasing prevalence of oral HPV infections, suggests a more complete and thorough investigation of these inter-relationships is needed. This study is among the first to examine these relationships and provide specific information about $p 53$-specific pathway modulation and MTHFR genotypes in oral cancers, which may be particularly useful to oncologists and oral health researchers as they develop rubrics for generalizing the effects and most effective treatment options for patients with oral cancer.

\footnotetext{
Abbreviations

HPV: Human papillomavirus; MTHFR: methylenetetrahydrofolate reductase; Rb: retinoblastoma; FDA: US Food and Drug Administration; ATCC: American Type Culture Collection; DMEM: Dulbecco's Modified Eagle's Medium; FA: Folic acid; mTF: Mock transfectants; RFI: relative-fold increase; PCR: polymerase chain reaction; GAPDH: Glyceraldehyde 3-phosphate dehydrogenase; RFLP: restriction fragment length polymorphisms
}

\section{Acknowledgements}

This research was supported, in part, by an Institutional Research Grant award from the American Cancer Society to KK (ACS-IRG\#103719), the University of Nevada, Las Vegas (UNLV) Office of Sponsored Programs, the UNLV School of Dental Medicine (UNLV-SDM) Office of Research and Biomedical Sciences Department.

\section{Author details}

${ }^{1}$ Department of Biomedical Sciences, School of Dental Medicine, University of Nevada, Las Vegas, USA. ${ }^{2}$ School of Life Sciences, College of Sciences, University of Nevada, Las Vegas, USA. ${ }^{3}$ College of Dental Medicine, Columbia University, New York, USA. ${ }^{4}$ College of Sciences, University of Nevada, Reno, USA. ${ }^{5}$ School of Health Related Professions: Nutrition, University of Medicine and Dentistry, New Jersey, USA. ${ }^{6}$ Department of Food and Beverage, Harrah Hotel College, University of Nevada, Las Vegas, USA.

\section{Authors' contributions}

KK, MAK and CJB conceived and designed this project. MM, OK, MR, JM, SC, $J H, J S, G R$ and KK were responsible for performing the experimental assays, data collection, figure generation, and writing. MAK and KK were responsible for editing the final manuscript. All authors read and approved the final manuscript.

\section{Competing interests}

The authors declare that they have no competing interests.

Received: 19 September 2011 Accepted: 23 March 2012

Published: 23 March 2012

\section{References}

1. Williams HK: Molecular pathogenesis of oral squamous carcinoma. Mol Pathol 2000, 53:165-172.

2. Campo-Trapero J, Cano-Sanchez J, Palacios-Sanchez B, Sanchez-Gutierrez JJ, Gonzalez-Moles MA, Bascones-Martinez A: Update on molecular pathology in oral cancer and precancer. Anticancer Res 2008, 28:1197-1205.

3. Marshberg A, Boffetta P, Winkelman R, Garfinkel L: Tobacco smoking, alcohol drinking, and cancer of the oral cavity and oropharynx among U.S. veterans. Cancer 1993, 72:1369-1375.

4. Blot WJ, McLaughlin JK, Winn DM, Austin DF, Greenberg RS, PrestonMartin S, Bernstein L, Schoenberg JB, Stemhagen A, Fraumeni JF Jr: Smoking and drinking in relation to oral and pharyngeal cancer. Cancer Res 1998, 489:3282-3287.

5. La Vecchia C, Negri E, Pelucchi C, Franceschi S: Dietary folate and colorectal cancer. Int J Cancer 2002, 102:545-547.

6. Poschl G, Stickel F, Wang SX, Seitz HK: Alcohol and cancer: genetic and nutritional aspects. Proc Nutr Soc 2004, 63:65-71.

7. Gillison ML, Koch WM, Capone RB, Spafford M, Westra WH, Wu L, Zahurak ML, Daniel RW, Viglione M, Symer DE, Shah KV, Sidransky D: Evidence for a causal association between human papillomavirus and a subset of head and neck cancers. J Natl Cancer Inst 2000, 92(9):709-720.

8. van Houten VM, Snijders PF, van den Brekel MW, Kummer JA, Meijer CJ, van Leeuwen B, Denkers F, Smeele LE, Snow GB, Brakenhoff RH: Biological evidence that human papillomaviruses are etiologically involved in a subgroup of head and neck squamous cell carcinomas. Int J Cancer 2001, 93:232-235.

9. Ha PK, Pai SI, Westra WH, Gillison ML, Tong BC, Sidransky D, Califano JA: Real-time quantitative PCR demonstrates low prevalence of human papillomavirus type 16 in premalignant and malignant lesions of the oral cavity. Clin Cancer Res 2002, 8(5):1203-1209.

10. Dai M, Clifford GM, le Calvez F, Castellsague X, Snijders PJ, Pawlita M, Herrero R, Hainaut $P$, Franceschi S: Human papillomavirus type 16 and TP53 mutation in oral cancer: matched analysis of the IARC multicenter study. Cancer Res 2004, 64(2):468-471.

11. Werness BA, Levine AJ, Howley PM: Association of human papillomavirus types 16 and 18 E6 proteins with p53. Science 1990, 248(4951):76-79.

12. Kingsley K, Johnson D, O'Malley S: Transfection of oral squamous cell carcinoma with human papillomavirus-16 induces proliferative and morphological changes independent of cellular adhesion in vitro. Cancer Cell Int 2006, 6:14

13. Reddout N, Christensen T, Bunnell A, Jensen D, Johnson D, O'Malley S, Kingsley K: High risk HPV types 18 and 16 are potent modulators of oral squamous cell carcinoma phenotypes in vitro. Infect Agent Cancer 2007, 2(1):21.

14. Walboomers JMM, Jacobs MV, Manos MM, Bosch FX, Kummer JA, Shah KV, Snijders PJF, Peto J, Meijer CJLM, Munoz N: Human papillomavirus is a necessary cause of invasive cervical cancer worldwide. J Pathol 1999, 189:12-19. 
15. Burnett TS, Sleeman JP: Uneven distribution of methylation sites within the human papillomavirus la genome: possible relevance to viral gene expression. Nucleic Acids Res 1984, 12:8847-8860.

16. List HJ, Patzel V, Zeidler U, Schopen A, Ruhl G, Stollwerk J, Klock G: Methylation sensitivity of the enhancer from the human papillomavirus type 16. J Biol Chem 1994, 269:11902-11911.

17. Stunkel W, Huang Z, Tan SH, O'Connor M, Bernard HU: Nuclear matrix attachment regions of human papillomavirus-16 repress or activate the E6 promoter depending on the physical state of the viral DNA. J Virol 2000, 74:2489-2501.

18. Paulsen M, Ferguson-Smith AC: DNA methylation in genomic imprinting, development, and disease. J Pathol 2001, 195:97-110.

19. Badal V, Chuang LSH, Tan EHH, Badal S, Villa LL, Wheeler CM, Li BFL, Bernard HU: CpG methylation of human papillomavirus type 16 DNA in cervical cancer cell lines and in clinical specimens: genomic hypomethylation correlates with carcinogenic progression. J Virol 2003, 77:6277-6234.

20. Subar AF, Block G, James LD: Folate intake and food sources in the US population. Am J Clin Nutr 1989, 50:508-516.

21. Bailey LB, Gregory JF: Folate metabolism and requirements. J Nutr 1999, 129:779-782

22. Eto I, Krumkeick CL: Role of vitamin B12 and folate deficiencies in carcinogenesis. Adv Exp Med Biol 1986, 206:313-330.

23. Giovannucci E, Rimm EB, Ascherio A, Stampfer MJ, Golditz GA, Willett WC: Alcohol, low-methionine-low-folate diets, and risk of colon cancer in men. J Nat Cancer Inst 1995, 87:265-273.

24. Rothenberg SP: Increasing the dietary intake of folate: pros and cons. Semin Hematol 1999, 36:65-74.

25. Flynn MA, Anderson WA, Burke SJ, Reilly A: Session 1: Public health nutrition. Folic acid food fortification: the Irish experience. Proc Nutr Soc 2008, 67:381-389.

26. La Vecchia C, Franceschi S, Levi F, et al: Diet and human oral carcinoma in Europe. Eur J Cancer B Oral Oncol 1993, 29B:17-22.

27. Pelucchi C, Talamini R, Negri E, Levi F, Conti E, Franceschi S, La Vecchia C: Folate intake and risk of oral and pharyngeal cancer. Ann Oncol 2003, 13:1677-1681.

28. Gabriel HE, Crott JW, Ghandour H, Dallal GE, Choi SW, Keyes MK, Jang H, Liu Z, Nadeau M, Johnston A, Mager D, Mason JB: Chronic cigarette smoking is associated with diminished folate status, altered folate form distribution, and increased genetic damage in the buccal mucosa of healthy adults. Am J Clin Nutr 2006, 83:835-841.

29. Capaccio P, Ottaviani F, Cuccarini V, Cenzuales S, Cesana BM, Pignataro L: Association between methylenetetrahydrofolate reductase polymorphisms, alcohol intake and oropharyngolaryngeal carcinoma in northern Italy. J Laryngol Otol 2005, 119:371-376.

30. Vairaktaris E, Yapijakis C, Kessler P, Vylliotis A, Ries J, Wiltfang J, Vassiliou S, Derka S, Neukam FW: Methylenetetrahydrofolate reductase polymorphism and minor increase of risk for oral cancer. J Cancer Res Clin Oncol 2006, 132:219-222.

31. Jacques PF, Selhub J, Bostom AG, Wilson PW, Rosenberg $\Vdash H$ : The effect of folic acid fortification on plasma folate and total homocysteine concentrations. N Engl J Med 1999, 340:1449-1454.

32. Dietrich M, Brown CJ, Block G: The effect of folate fortification of cerealgrain products on blood folate status, dietary folate intake, and dietary folate sources among adult non-supplement users in the United States. J Am Coll Nutr 2005, 24:266-274.

33. Stolzenberg-Solomon RZ, Chang SC, Leitzmann MF, et al: Folate intake, alcohol use, and postmenopausal breast cancer risk in the Prostate, Lung, Colorectal, and Ovarian Screening Trial. Am J Clin Nutr 2006 83:895-904.

34. Cole BF, Baron JA, Sandler RS, et al: Folic acid for the prevention of colorectal adenomas: a randomized clinical trial. JAMA 2007, 297:2351-2359.

35. Kingsley K, Zuckerman J, Davis M, Matteucci M, Knavel A, Rinehart J, Tran V, Woyciehowsky D, Jenkins P, Yu Rui, Nguyen DH, O'Malley S: Induction of Differential Growth in vitro by High-risk Human Papillomavirus in Human Breast Cancer Cell Lines is Associated with Caspase Dysregulation. J Cancer and Ther 2009, 1(2):62-71.

36. McCabe J, Hajibandeh J, Tran MD, Meeder CA, Sharma K, Nguyen DH, Moody M, Keiserman MA, Bergman CJ, Kingsley K: Folate supplementation induces differential dose-dependent modulation of proliferative phenotypes among cancerous and non-cancerous oral cell lines in vitro. J Diet Supp/ 2010, 7(4):325-340.

37. Bailey RL, Dodd KW, Gahche JJ, Dwyer JT, McDowell MA, Yetley EA Sempos CA, Burt VL, Radimer KL, Picciano MF: Total folate and folic acid intake from foods and dietary supplements in the United States: 20032006. Am J Clin Nutr 2010, 91(1):231-237.

38. Matsue H, Rothberg KG, Takashima A, Kamen BA, Anderson RG, Lacey SW: Folate receptor allows cells to grow in low concentrations of 5methyltetrahydrofolate. Proc Natl Acad Sci USA 1992, 89:6006-6009.

39. King M, Chatelain K, Farris D, Jensen D, Pickup J, Swapp A, O'Malley S, Kingsley K: Oral squamous cell carcinoma proliferative phenotype is modulated by proanthocyanidins: a potential prevention and treatment alternative for oral cancer. BMC Complement Altern Med 2007, 7:22.

40. Hays WL: Inferences about population means. Statistics. 5 edition. International Thomson Publishing; 1994, 311-42.

41. Mu LN, Cao W, Zhang ZF, Yu SZ, Jiang QW, You NC, Lu QY, Zhou XF, Ding BG, Chang J, Chen CW, Wei GR, Cai L: Polymorphisms of 5,10methylenetetralydrofolate reductase (MTHFR), fruit and vegetable intake, and the risk of stomach cancer. Biomarkers 2007, 12(1):61-75.

42. Frosst P, Blom HJ, Milos R, Goyette P, Sheppard CA, Matthews RG, Boers GJ, den Heijer M, Kluijtmans LA, van den Heuvel LP, et al: A candidate genetic risk factor for vascular disease: a common mutation in methylenetetrahydrofolate reductase. Nat Genet 1995, 10:111-113.

43. van der Put NM, Gabreëls F, Stevens EM, Smeitink JA, Trijbels FJ, Eskes TK, van den Heuvel LP, Blom HJ: A second common mutation in the methylenetetrahydrofolate reductase gene: an additional risk factor for neural-tube defects? Am J Hum Genet 1998, 62:1044-1051.

44. Wolter F, Turchanowa L, Stein J: Resveratrol-induced modification of polyamine metabolism is accompanied by induction of c-Fos. Carcinogenesis 2003, 24:469-474.

45. Vakifahmetoglu H, Olsson M, Orrenius S, Zhivotovsky B: Functional connection between p53 and caspase- 2 is essential for apoptosis induced by DNA damage. Oncogene 2006, 25:5683-5692.

46. Chatelain K, Phippen S, McCabe J, Teeters CA, O'Malley S, Kingsley K: Cranberry and Grape Seed Extracts Inhibit the Proliferative Phenotype of Oral Squamous Cell Carcinomas. Evid Based Complement Alternat Med 2008.

47. Kingsley K, Jensen D, Toponce R, Dye J, Martin D, Phippen S, Ross D, Halthore VS, O'Malley S: Inhibition of Oral Cancer Growth in Vitro Is Modulated Through Differential Signaling Pathways by Over-the-Counter Proanthocyanidin Supplements. J Diet Supp/ 2010, 7(2):130-144.

48. Weinstein SJ, Gridley G, Harty LC, Diehl SR, Brown LM, Winn DM, BravoOtero E, Hayes RB: Folate intake, serum homocysteine and methylenetetrahydrofolate reductase (MTHFR) C677T genotype are not associated with oral cancer risk in Puerto Rico. J Nutr 2002, 132:762-767.

49. Vairaktaris E, Yapijakis C, Kessler P, Vylliotis A, Ries J, Wiltfang J, Vassiliou S, Derka S, Neukam FW: Methylenetetrahydrofolate reductase polymorphism and minor increase of risk for oral cancer. J Cancer Res Clin Oncol 2006, 132:219-222.

50. Hsu S, Singh B, Schuster G: Induction of apoptosis in oral cancer cells: agents and mechanisms for potential therapy and prevention. Oral Oncol 2004, 40(5):461-73, Review.

51. Lun M, Zhang PL, Pellitteri PK, Law A, Kennedy TL, Brown RE: Nuclear factor-kappaB pathway as a therapeutic target in head and neck squamous cell carcinoma: pharmaceutical and molecular validation in human cell lines using Velcade and siRNA/NF-kappaB. Ann Clin Lab Sci 2005, 35:251-258.

52. Skvortsov S, Skyortsova I, Stasyk T, Schiefermeier N, Neher A, Gunkel AR, Bonn GK, Huber LA, Lukas P, Pleiman CM, Zwierzina H: Antitumor activity of CTFB, a novel anticancer agent, is associated with the downregulation of nuclear factor-kappaB expression and proteasome activation in head and neck squamous carcinoma cell lines. Mol Cancer Ther 2007, 6:1898-1908.

53. Bock JM, Menon SG, Goswami PC, Sinclair LL, Bedford NS, Jackson RE, Trask DK: Differential activity of sulindac metabolites against squamous cell carcinoma of the head and neck is mediated by p21waf1/cip1 induction and cell cycle inhibition. Cancer Biol Ther 2007, 6:30-39.

54. Kingsley K: Potential effects of dietary folate supplementation on oral carcinogenesis, development and progression. J Diet Supp/ 2010, 7(1):51-59. 
55. Rosl FA, Arab A, Klevenz B, zur Hausen H: The effect of DNA methylation on gene regulation of human papillomaviruses. J Gen Virol 1993, 74:791-801.

56. Thain A, Jenkins $\mathrm{O}$, Clarke AR, Gaston K: CpG methylation directly inhibits binding of the human papillomavirus type 16 E2 protein to specific DNA sequences. J Virol 1996, 70:7233-7235.

57. Pfeifer GP, Denissenko MF, Olivier M, Tretyakova N, Hecht SS, Hainaut P: Tobacco smoke carcinogens, DNA damage and p53 mutations in smoking-associated cancers. Oncogene 2002, 21(48):7435-7451.

58. Cox LA Jr, Sanders E: Estimating preventable fractions of disease caused by a specified biological mechanism: PAHs in smoking lung cancers as an example. Risk Anal 2006, 26(4):881-892.

59. Francis DA, Schmid SI, Howley PM: Repression of the integrated papillomavirus E6/E7 promoter is required for growth suppression of cervical cancer cells. J Virol 2000, 74:2679-2686.

60. Dahler AL, Jones SJ, Dicker AJ, Saunders NA: Keratinocyte growth arrest is associated with activation of a transcriptional repressor element in the human cdk1 promoter. J Cell Physiol 1998, 177(3):474-482.

61. Qiu W, Schonleben F, Li X, Su GH: Disruption of transforming growth factor beta-Smad signaling pathway in head and neck squamous cell carcinoma as evidenced by mutations of SMAD2 and SMAD4. Cancer Lett 2007, 245(1-2):163-170

62. Tsai WC, Lin YC, Tsai ST, Shen WH, Chao TL, Lee SL, Wu LW: Lack of modulatory function of coding nucleotodie polymorphism S100A2 185 G > A in oral squamous cell carcinoma. Oral Dis 2011, 17(3):283-290.

63. Yang YY, Woo ES, Reese CE, Bahnson RR, Saijo N, Lazo JS: Human metallothionein isoform gene expression in cisplatin-sensitive and resistant cells. Mol Pharmacol 1994, 45(3):453-460.

64. Timmermann S, Hinds PW, Munger K: Re-expression of endogenous p16ink4a in oral squamous cell carcinoma lines by 5 -aza-2'deoxycytidine treatment induces a senesence-like state. Oncogene 1998, 17(26):3445-3453.

65. Chang X, Monitto CL, Demokan S, Kim MS, Chang SS, Zhong X, Califano JA, Sidransky D: Identification of hypermethylated genes associated with cisplatin resistance in human cancers. Cancer Res 2010, 70(7):2870-2879.

doi:10.1186/1475-2867-12-10

Cite this article as: Moody et al: Folic acid supplementation increases survival and modulates high risk HPV-induced phenotypes in oral squamous cell carcinoma cells and correlates with $p 53$ mRNA transcriptional down-regulation. Cancer Cell International 2012 12:10.

\section{Submit your next manuscript to BioMed Central and take full advantage of:}

- Convenient online submission

- Thorough peer review

- No space constraints or color figure charges

- Immediate publication on acceptance

- Inclusion in PubMed, CAS, Scopus and Google Scholar

- Research which is freely available for redistribution

Submit your manuscript at www.biomedcentral.com/submit
Biomed Central 